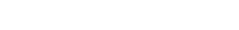

*For correspondence: simon delusignan@phc.ox.ac.uk

Competing interest: The authors declare that no competing interests exist.

Received: 06 April 2020

Accepted: 06 April 2020

Published: 16 April 2020

@This article is Open Access: CC BY license (https://creativecommons.org/licenses/by/4.0/)

Author Keywords: Practice organisation, primary healthcare, general practice, coronavirus

Copyright (C) 2020, The Authors;

DOI:10.3399/

bjgpopen20X101070

\section{To monitor the COVID-19 pandemic we need better quality primary care data}

\author{
Simon de Lusignan ${ }^{1 *}$, John Williams ${ }^{1}$ \\ ${ }^{1}$ Nuffield Department of Primary Care Health Sciences, University of Oxford, Oxford, \\ UK
}

UK primary care coding of covid-19 is a mess: we need to stop the use of bad codes, and migrate from the use of ugly to good codes, but will only be able to do so when they are finally released.

Key data computerised medical record (CMR) systems are recorded using 'codes', to standardise recording and so attendances about a medical problem can be linked. ${ }^{1}$ At the start of the COVID-19 pandemic there was neither international agreement about nomenclature nor codes available in primary care CMRs with which to record exposure, testing, or infection.

We have now been through three iterations of clinical codes in the UK since the end of January. Five temporary codes were added to all the primary care CMR systems using the '2019 nCoV (Wuhan)' label in January 2020. Subsequently NHS Digital, the NHS coding organisation, released a more extensive set of SNOMED CT concepts named '2019 nCoV (novel coronavirus)' because the use of 'Wuhan' had been deprecated; these codes were in turn replaced by 'SARS -CoV-2 (severe acute respiratory syndrome coronavirus 2$)^{\prime}{ }^{2}$

The situation has been further complicated by the fact that this last release is only now starting to become available in CMRs (Table 1), and because some clinicians have gone back to using old non-specific coronavirus codes (such as 'Suspected Coronavirus infection: $1 \mathrm{JX}$ ', and 'Coronavirus infection: A795').

This creates challenges for the surveillance system and others monitoring the pandemic. ${ }^{3}$ We have previously classified the incorrect use of codes as miscoding, misclassification, or misdiagnosis. ${ }^{4}$ In the cases of COVID-19, we are seeing ${ }^{1}$ both Miscoding (that is, continued use of the temporary codes, which should stop once the new ones are available); ${ }^{2}$ and Misclassification (use of nonspecific coronavirus codes), which should stop. Table 1 sets out the clinical concept we currently need to consistently record in primary care, the temporary codes available to do this, and the final codes we should all eventually use. Prompt cards to help clinicians and coders are available at: https://clininf.eu/index.php/cov-19/

All UK primary care clinicians and coders are recommended to continue to use the temporary codes until the new ones are available, then switch. Accurate data is a key to understanding and monitoring the course of this pandemic.

\section{Appendix: Examples of codes not to use}

- Exposure to coronavirus infection

- Suspected coronavirus infection

- Coronavirus infection

- Disease due to Coronaviridae

- Coronavirus contact 
Table 1 Clinical concepts that should be coded, temporary and definitive codes

\begin{tabular}{|c|c|c|}
\hline $\begin{array}{l}\text { Clinical concepts that } \\
\text { should be coded in } \\
\text { CMR }\end{array}$ & $\begin{array}{l}\text { Temporary codes } \\
\text { Go on using until replaced by } \\
\text { SARS-Cov-2 }\end{array}$ & $\begin{array}{l}\text { Final SNOMED CT description } \\
\text { Roll-out taking place during April } 2020\end{array}$ \\
\hline \multirow[t]{2}{*}{ Exposure to COVID-19 } & $\begin{array}{l}\text { Exposure to } 2019 \text { nCoV (Wuhan) } \\
\text { infection or }\end{array}$ & \multirow[t]{2}{*}{ Exposure to SARS-CoV-2 infection } \\
\hline & $\begin{array}{l}\text { Exposure to } 2019 \mathrm{nCoV} \text { (novel } \\
\text { coronavirus) infection }\end{array}$ & \\
\hline \multirow[t]{2}{*}{$\begin{array}{l}\text { Suspected COVID-19 } \\
\text { infection }\end{array}$} & $\begin{array}{l}\text { Suspected } 2019 \text { nCoV (Wuhan) } \\
\text { infection or }\end{array}$ & \multirow[t]{2}{*}{ Suspected COVID-19 } \\
\hline & $\begin{array}{l}\text { Suspected } 2019 \mathrm{nCoV} \text { (novel } \\
\text { coronavirus) infection }\end{array}$ & \\
\hline \multirow[t]{5}{*}{$\begin{array}{l}\text { Test for COVID-19 } \\
\text { offered or taken }\end{array}$} & No specific codes & $\begin{array}{l}\text { Swab for SARS-CoV-2 (severe acute respiratory } \\
\text { syndrome coronavirus 2) taken by healthcare } \\
\text { professional }\end{array}$ \\
\hline & & $\begin{array}{l}\text { Self-taken swab for SARS-CoV-2 (severe acute } \\
\text { respiratory syndrome coronavirus 2) offered }\end{array}$ \\
\hline & & $\begin{array}{l}\text { Self-taken swab for SARS-CoV-2 (severe acute } \\
\text { respiratory syndrome coronavirus 2) completed }\end{array}$ \\
\hline & $\begin{array}{l}\text { Tested for } 2019 \text { nCoV (Wuhan) } \\
\text { infection or }\end{array}$ & \\
\hline & $\begin{array}{l}\text { Tested for } 2019 \text { nCoV (novel } \\
\text { coronavirus) infection }\end{array}$ & \\
\hline \multirow[t]{2}{*}{ COVID-19 definite case } & $\begin{array}{l}\text { Confirmed } 2019 \text { nCoV (Wuhan) } \\
\text { infection or }\end{array}$ & \multirow[t]{2}{*}{ COVID-19 } \\
\hline & $\begin{array}{l}\text { Confirmed } 2019 \mathrm{nCoV} \text { (novel } \\
\text { coronavirus) infection }\end{array}$ & \\
\hline \multirow[t]{2}{*}{ COVID-19 excluded } & $\begin{array}{l}\text { Excluded } 2019 \text { nCoV (Wuhan) } \\
\text { infection or }\end{array}$ & \multirow[t]{2}{*}{ COVID-19 excluded } \\
\hline & $\begin{array}{l}\text { Excluded } 2019 \text { nCoV (novel } \\
\text { coronavirus) infection }\end{array}$ & \\
\hline
\end{tabular}

Laboratory test codes

COVID-19 confirmed by lab test

COVID-19 confirmed by laboratory test

COVID-19 excluded by lab test

COVID-19 excluded by laboratory test

COVID-19 virus detected 2019-nCoV (novel coronavirus)

SARS-CoV-2 (severe acute respiratory syndrome detected coronavirus 2) detected

COVID-19 virus not 2019-nCoV (novel coronavirus) not SARS-CoV-2 (severe acute respiratory syndrome

detected detected

coronavirus 2) not detected

$\mathrm{CMR}=$ computerised medical record

\section{Funding}

N/A

\section{Ethical approval}

$\mathrm{N} / \mathrm{A}$

\section{Provenance}

Commissioned; not externally peer reviewed. 


\section{References}

1. de Lusignan S. Codes, classifications, terminologies and nomenclatures: definition, development and application in practice. Inform Prim Care 2005; 13(1): 65-70. DOI: https://doi.org/10.14236/jhi.v13i1.580

2. Coronaviridae Study Group of the International Committee on Taxonomy of Viruses. The species severe acute respiratory syndrome-related coronavirus: classifying 2019-nCoV and naming it SARS-CoV-2. Nat Microbiol 2020; 5(4): 536-544. DOI: https://doi.org/10.1038/s41564-020-0695-z

3. de Lusignan S, Lopez Bernal J, Zambon M, et al. Emergence of a novel coronavirus (COVID-19): protocol for extending surveillance used by the Royal College of general practitioners research and surveillance centre and public health England. JMIR Public Health Surveill 2020; 6(2): e18606. DOI: https://doi.org/10.2196/18606

4. de Lusignan S, Sadek N, Mulnier H, et al. Miscoding, misclassification and misdiagnosis of diabetes in primary care. Diabet Med 2012; 29(2): 181-189. DOI: https://doi.org/10.1111/j.1464-5491.2011.03419.x 